Eur. J. Clin. Chem. Clin. Biochem.

Vol. 32, 1994, pp. 279-284

(c) 1994 Walter de Gruyter \& Co. Berlin - New York

\title{
In Vitro Effects of Hypoxia and Reoxygenation on Human Umbilical Endothelial Cells ${ }^{1}$
}

\author{
By A. Windischbauer, Andrea Griesmacher and M. M. Müller
}

2nd Department of Surgery, Clinical Biochemistry, University of Vienna, Vienna, Austria

(Received May 17/August 6, 1993)

Dedicated to Prof. Dr. Dr. Helmut Greiling on the occasion of his 65 th birthday

Summary: We investigated metabolic changes in human umbilical venous endothelial cells, when these were incubated under hypoxic followed by hyperoxic conditions, thus simulating hypoxia and reoxygenation. The human umbilical venous endothelial cells were incubated with a degassed buffer (oxygen content: $0-0.5 \%$ ) for either $3 \mathrm{~h}$ or $24 \mathrm{~h}$, followed by a 60 min incubation with oxygen-perfused buffer (oxygen content: $100 \%$ ). Three hours of hypoxia led to a slight decrease in the ATP and creatine phosphate content $(-16 \% \pm 5 \%)$, while a pronounced decrease of high energy phosphates $(-54 \% \pm 4 \%)$ was observed after $24 \mathrm{~h}$ of hypoxia. Reoxygenating the cells after $3 \mathrm{~h}$ of hypoxia led to restoration of the content of high energy phosphates, while reoxygenation after $24 \mathrm{~h}$ resulted in a strong decrease $(-66 \% \pm 4 \%)$. The prostaglandin $I_{2}$ release during the first $3 \mathrm{~h}$ of hypoxia exceeded the release in the following $21 \mathrm{~h}$. In all cases, reoxygenation increased the prostaglandin $\mathrm{I}_{2}$ release. Under normoxic conditions the ratio between oxidised glutathione and reduced glutathione shifted from $1: 100$ to $1: 4.5$ after $3 \mathrm{~h}$ of hypoxia. The content of lipid peroxidation products was almost unaffected during hypoxia, whereas reoxygenation resulted in a pronounced increase $(+380 \% \pm 60 \%)$. The results of this in vitro study suggest that relatively long periods of hypoxia lead to a deficiency of high energy phosphates in the cell. Reoxygenation leads to the formation of oxygen-derived radicals, irrespectively of a prior hypoxia.

\section{Introduction}

Oygen-derived radicals play àn essential role in tissue damage (1). The potential sources of toxic oxygen species generated during ischaemia and reoxygenation included prostaglandin biosynthesis, mitochondrial electron transport systems, purine catabolism by means of xanthine oxidase and infiltration by phagocytes $(2-6)$.

It is generally accepted that hypoxia and reoxygenation increase the formation of oxygen-derived free radicals. Modifications of intracellular enzymes and membranes result from the exhausted capacity of the antioxidant defence mechanisms (7). Previous in vitro investigations

\footnotetext{
') This project was supported by the "Medizinisch-Wissenschaftlicher Fonds des Bürgermeisters der Bundeshauptstadt Wien".
}

used radical-generating systems such as xanthine/xanthine oxidase or hydrogen peroxides $\left(\mathrm{H}_{2} \mathrm{O}_{2}\right)$ to study the effects of radicals on cell metabolism $(8-10)$. Our present study, using human umbilical venous endothelial cells investigates the effects of hypoxia on cell metabolism.

The influence of hypxia and reoxygenation on the intracellular content of high energy phosphates, the release of lactate dehydrogenase, glucose consumption, the ratio between reduced and oxidised glutathione and formation of lipid peroxidation products were determined. In addition, possible effects on prostaglandin $I_{2}$ production were evaluated, since it was reported that an initial release of fatty acids from membrane phospholipids occurs during ischaemia, due to phospholipase activation and ATP-dependent fatty acid acylation inhibition (11). 


\section{Material and Methods}

Cell culture

Endothelial cells were prepared using human venous umbilical veins. Cells were isolated and cultured according to a modified standard procedure reported by Jaffe (9). Briefly, fresh human umbilical veins were filled with $1 \mathrm{~g} / \mathrm{l}$ collagenase solution and incubated at $37^{\circ} \mathrm{C}$ for $5 \mathrm{~min}$. Thereafter the veins were perfused with M 199 (Gico, USA) medium containing $200 \mathrm{ml} / 1$ human serum (pH 7.4). Cells were collected from the perfusate by centrifugation at $800 \mathrm{~g}$ for $5 \mathrm{~min}$ and seeded into culture T-75 flasks precoated with human fibronectin (Biomedica, Austria). Cells were cultured in $\mathrm{M} 199$ medium ( $\mathrm{pH} \mathrm{7.4)} \mathrm{containing} 200 \mathrm{ml} / 1$ human serum, $100000 \mathrm{U} / \mathrm{l}$ low molecular weight heparin (Sigma, Germany) and $30 \mathrm{mg} / \mathrm{l}$ bovine hypothalamic growth factor (Biomedica, Austria). The confluent primary monolayers were washed and trypsinized. Cell suspensions were transferred either into the wells of a 24well culture plate (determination of ATP, creatine phosphate and prostaglandin $\mathrm{I}_{2}$ ) or the wells of a 6-well culture plate (determination of thiobarbituric acid reactive substances, reduced glutathione and oxidised glutathione). Cells were cultivated for four days. Only confluent cells from these first subcultures (24-well culture plate: approx. 140000 cells/well, 6-well culture plate: approx. 580000 cells/well) were used for the experiments described below. The cells were identified as endothelial cells by the typical cobblestone, contact-inhibited morphology (13) and by factor VIII (14) staining. : 1

\section{Exposure of cells to hypoxia and reoxygenation}

The culture medium was removed and the cell layers were gently washed with preheated $\left(37^{\circ} \mathrm{C}\right)$ phosphate-buffered saline (containing $2.2 \mathrm{mmol} / 1 \mathrm{Ca}^{2+}, 0.5 \mathrm{mmol} / 1 \mathrm{Mg}^{2+}$ and $5 \mathrm{mmol} / \mathrm{l}$ glucose). A degassed phosphate buffered saline was used for the incubation, which had been perfused with $100 \% \mathrm{~N}_{2}$ for $20 \mathrm{~min}$. The $\mathrm{O}_{2}$ content was approx. $0-0.5 \%$. The culture plates were placed in a modified incubator which allowed handling under low oxygen tension $\left(1-2 \% \mathrm{O}_{2}\right)$, which was monitored by means of a WTW Oxi96 oximeter (WTW, Germany). The cell layers were incubated with the degassed and perfused buffer. After incubation the culture plates were placed in an absolutely airtight chamber filled with $100 \% \mathrm{~N}_{2}$ for 3 and $24 \mathrm{~h}$, respectively. The oxygen tension in the medium closely paralleled that in the gas phase. All experiments were performed at $37^{\circ} \mathrm{C}$. At the end of the incubation the plates were divided into two groups. One group (hypoxia group) was used to determine the metabolic effects of hypoxia ( 3 and $24 \mathrm{~h}$ ). For the second group (hypoxia reoxygenation group) phosphate buffered saline was perfused with $100 \% \mathrm{O}_{2}$ for $20 \mathrm{~min}$, then used to simulate a $60 \mathrm{~min}$ reoxygenation after hypoxia. The $\mathrm{O}_{2}$ content of the buffer was four times higher than normal ( 35 versus $8.8 \mathrm{mg} / \mathrm{l} \mathrm{O}_{2}$ ). Cell culture plates were incubated and placed in the chamber for $60 \mathrm{~min}$. The chamber was filled with $100 \% \mathrm{O}_{2}$. Control experiments for both groups were incubated with air-equilibrated phosphate buffered saline (normoxia group) for the same incubation period. To investigate the effects of a high oxygen content, human umbilical venous endothelial cells were also incubated with the hyperoxic phosphate buffered saline (normoxia/reoxygenation group). The $\mathrm{pH}$ was recorded after every hypoxic and reoxygenation exposure and remained stable.

Determination of intracellular ATP and creatine phosphate content

Intracellular ATP and creatine phosphate contents were determined using cell lysates obtained by the addition of $250 \mu \mathrm{l}$ of $0.5 \mathrm{~mol} / \mathrm{l}$ $\mathrm{HClO}_{4}$ to each well. Lysates were neutralised with a $1 \mathrm{~mol} / 1 \mathrm{~K}_{2} \mathrm{CO}_{3}$ solution, transferred into cups, centrifuged and supernatants analysed for ATP and creatine phosphate. Creatine phosphate was determined after conversion to ATP using creatine kinase, with ADP as substrate and $\mathrm{N}$-acetylcysteine as an activator. ATP was mea- sured by bioluminescence using an ATP-monitoring reagent and a 1251-Luminometer (LKB, Sweden) as described earlier (15).

Determination of glucose consumption and lactate dehydrogenase

Glucose and the activity of lactate dehydrogenase in the incubation buffer were measured photometrically on an Ektachem XR700 (Kodak, USA) analyser.

\section{Determination of prostaglandin $\mathrm{I}_{2}$ release}

At the end of the incubations the supernatants of the cell layers were transferred into micro-test tubes containing indomethacin (30 $\mu \mathrm{mol} / \mathrm{l}$ final concentration) to prevent any further eicosanoid formation by single detached cells; the tubes were stored at $-70^{\circ} \mathrm{C}$ until analysis. The stable degradation product of prostaglandin $\mathrm{I}_{2}$, 6-keto-prostaglandin $F_{1 \alpha}$, was measured by a radioimmunoassay (RIA) from BIOTECX, USA. Neither the buffer itself nor any of the agents used in these experiments showed interference with the RIA. Reliability and specificity of the assays were confirmed, using the cyclooxygenase inhibitor, indomethacin. The cross-reactivities of the RIA were reported recently (16).

Determination of intracellular reduced glutathione and oxidised glutathione

The simultaneous determination of reduced glutathione and oxidised glutathione was carried out using selectively active enzymes as described in l.c. (17). Cells were lysed by adding $750 \mu \mathrm{l}$ of 0.5 $\mathrm{mol} / / \mathrm{HClO}_{4}$ to each well. The lysates were neutralised with a $1 \mathrm{~mol} / \mathrm{l} \mathrm{K}_{2} \mathrm{CO}_{3}$ solution, the cell suspensions of 3 wells were pooled, transferred into cups, then centrifuged, followed by determination of reduced glutathione and oxidised glutathione. Reduced glutathione was determined photometrically as S-lactyl-glutathione after converting reduced glutathione into S-lactyl-glutathione using glyoxalase-I in the presence of methylglyoxal. Oxidised glutathione was determined photometrically by the decrease of added $\mathrm{NADPH}$ in the presence of glutathione reductase.

\section{Determination of lipid peroxidation products}

The phosphate buffered saline was removed from the cell layers and $1 \mathrm{ml} 20 \mathrm{mg} / \mathrm{kg}$ aqueous butyl-bydroxy-anisol solution was added to each well. Lipid peroxidation products were determined (18) as thiobarbituric acid reactive substances.

\section{Statistical analysis}

Values are expressed as mean $\pm \mathrm{SD}$. For the determination of the statistical significance a matched pairs-T-test was used.

\section{Results}

\section{ATP, creatine phosphate and glucose}

Three hours of hypoxia had no effect on the ATP content. However, the creatine phosphate content decreased by $23.9 \%$ compared with controls. Subssequent hyperoxic conditions for $60 \mathrm{~min}$ resulted in a restoration of the creatine phosphate content, whëreas ATP remained stable (tab. 1). Twenty four hours of hypoxia had a pronounced effect on the content of high energy phosphates. Both ATP and creatine phosphate concentrations decreased dramatically (tab. 2j): A 60 min period of re- 
Tab. 1 Contents of ATP, creatine phosphate and thiobarbituric acid reactive substances after $3 \mathrm{~h}$ of hypoxia and $3 \mathrm{~h}$ hypoxia followed by $60 \mathrm{~min}$ of reoxygenation.

\begin{tabular}{|c|c|c|c|c|c|}
\hline & & $\begin{array}{l}\text { Normoxia group } \\
3 \mathrm{~h}\end{array}$ & $\begin{array}{l}\text { Hypoxia group } \\
3 \mathrm{~h}\end{array}$ & $\begin{array}{l}\text { Normoxial } \\
\text { reoxygenation group } \\
3 \mathrm{~h}+60 \text { min }\end{array}$ & $\begin{array}{l}\text { Hypoxia/ } \\
\text { reoxygenation } \\
\text { group } \\
3 \mathrm{~h}+60 \mathrm{~min}\end{array}$ \\
\hline ATP & $\begin{array}{l}\text { nmol/ } / 10^{6} \text { cells } \\
\text { nmol } / 10^{6} \text { cells }\end{array}$ & $\begin{array}{l}10.8 \pm 0.3 \\
20.5 \pm 1.4 \\
33 \pm 2\end{array}$ & $\begin{array}{l}11.0 \pm 0.5 \\
15.6 \pm 2.3^{*} \\
36+4\end{array}$ & $\begin{array}{c}11.9 \pm 0.4 \\
22.0 \pm 4.6 \\
135 \pm 26^{* *}\end{array}$ & $\begin{array}{l}10.4 \pm 0.5 \\
23.0 \pm 3.2 \# \\
145 \pm 8 * \#\end{array}$ \\
\hline $\begin{array}{l}\text { Thiobarbituric acid } \\
\text { reactive substances }\end{array}$ & & & $36 \pm 4$ & $135 \pm 26^{*} \#$ & $145 \pm 8 * \#$ \\
\hline
\end{tabular}

* = statistically significant compared to normoxia group $(p<0.001)$

\# = statistically significant compared to hypoxia group $(\mathrm{p}<0.0010$

Values are given as mean $\pm S D(n=12)$.

Tab. 2 Contents of ATP, creatine kinase and thiobarbituric acid reactive substances after $24 \mathrm{~h}$ of hypoxia and $24 \mathrm{~h}$ hypoxia followed by $60 \mathrm{~min}$ of reoxygenation.

\begin{tabular}{|c|c|c|c|c|c|}
\hline & & $\begin{array}{l}\text { Normoxia group } \\
3 \mathrm{~h}\end{array}$ & $\begin{array}{l}\text { Hypoxia group } \\
3 \mathrm{~h}\end{array}$ & $\begin{array}{l}\text { Normoxial } \\
\text { reoxygenation group } \\
3 h+60 \text { min }\end{array}$ & $\begin{array}{l}\text { Hypoxia/ } \\
\text { reoxygenation } \\
\text { group } \\
3 \mathrm{~h}+60 \mathrm{~min}\end{array}$ \\
\hline $\begin{array}{l}\text { ATP } \\
\text { Creatine kinase } \\
\text { Thiobarbituric acid } \\
\text { reactive substances }\end{array}$ & $\begin{array}{l}\mathrm{nmol} / 10^{6} \text { cells } \\
\mathrm{nmol} / 10^{6} \text { cells } \\
\mathrm{pmol} / 10^{6} \text { cells }\end{array}$ & $\begin{array}{l}10.6 \pm 0.6 \\
19.8 \pm 5.1 \\
35 \pm 4\end{array}$ & $\begin{aligned} 4.9 & \pm 0.3^{*} \\
9.6 & \pm 1.0^{*} \\
46 & \pm 6\end{aligned}$ & $\begin{array}{c}11.7 \pm 0.5 \\
21.2 \pm 1.5 \\
140 \pm 20^{*} \#\end{array}$ & $\begin{aligned} 6.2 & \pm 0.5^{*} \\
5.3 & \pm 1.5^{* \#} \\
147 & \pm 20^{* \#}\end{aligned}$ \\
\hline
\end{tabular}

* = statistically significant compared with normoxia group $(p<0.001)$

\# = statistically significant compared with hypoxia group $(p<0.001)$

Values are given as mean $\pm S D(n=12)$.

oxygenation following $24 \mathrm{~h}$ of hypoxia slightly increased the ATP content compared with the hypoxic state. In contrast, the creatine phosphate content decreased further. Thus, an overall decrease of total high energy phosphate was observed (tab. 2). No significant differences in the ATP and creatine phosphate contents were detectable after 60 min of rexoxygenation without hypoxic pretreatment, in comparison with control experiments. Basic glucose consumption during $3 \mathrm{~h}$ of normoxic and hypoxic conditions were $1.5 \pm 0.4$ and $1.5 \pm 0.5 \mu \mathrm{mol} / 10^{6}$ cells, respectively. Twenty four hours of incubation increased the glucose consumption of normoxic cells and had an even greater effect on hypoxic cells: $2.2 \pm 0.6$ and $4.5 \pm 0.9 \mu \mathrm{mol} / 10^{6}$ cells, respectively.

\section{Release of lactate dehydrogenase}

Three and $24 \mathrm{~h}$ of hypoxia resulted in slight increase of the extracellular lactate dehydrogenase activity, although these increases were not statistically significant (fig. 1). In contrast, reoxygenation led to a strong increase in the lactate dehydrogenase release. Similar effects were observed with and without hypoxic pretreatment. The highest extracellular lactate dehydrogenase activity was found after $24 \mathrm{~h}$ hypoxia followed by reoxygenation, but this was not significantly different from the corresponding normoxic controls.

\section{Prostaglandin $\mathrm{I}_{2}$}

Duration of hypoxia played a key role in prostaglandin $\mathrm{I}_{2}$ release. Three hours of hypoxia led to an increase of prostaglandin $I_{2}$ levels to values approximately $240 \%$ higher than those determined in normoxic control experiments. Twenty four hours of hypoxia further enhanced the total prostaglandin $\mathrm{I}_{2}$ release.

Reoxygenation for $60 \mathrm{~min}$ led to a pronounced increase in prostaglandin $\mathrm{I}_{2}$ release. Hypoxic pretreatment diminished this "reperfusion release". The results are shown in figure 2.

\section{Reduced glutathione and oxidised glutathione}

Under normoxic conditions the ratio between oxidised glutathione and reduced glutathione was $1: 100$ (fig. 3). After $3 \mathrm{~h}$ of hypoxia the oxidised glutathione : reduced glutathione ratio shifted to $1: 4.5$, the subsequent reoxygenation led to a further increase in oxidised glutathione (oxidised glutathione : reduced glutathione ratio: $1: 2.4)$. After $24 \mathrm{~h}$ of hypoxia no intracellular reduced glutathione could be detected (data not shown). 

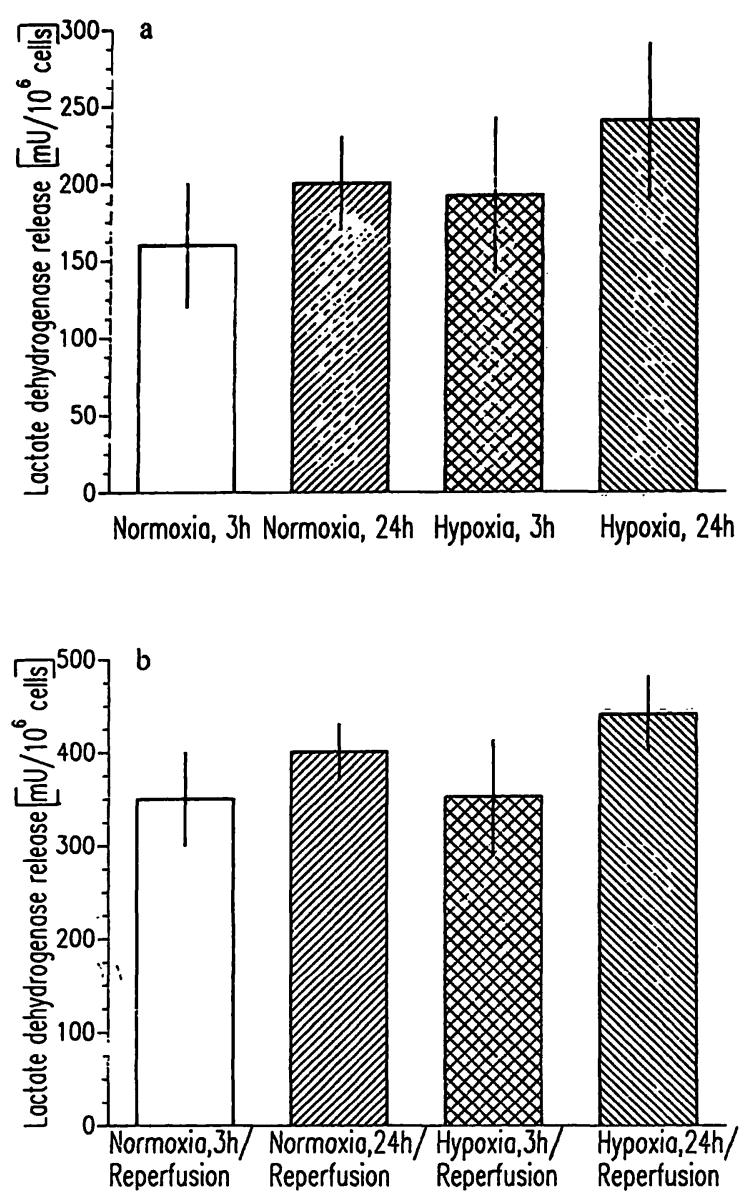

Fig. 1 Lactate dehydrogenase release from human umbilical venous endothelial cells after $3 \mathrm{~h}$ and $24 \mathrm{~h}$ of hypoxia before (a) and after $60 \mathrm{~min}$ of reoxygenation (b), $\mathrm{n}=11$.

\section{Thiobarbituric acid reaction substances}

Three and $24 \mathrm{~h}$ of hypoxia resulted in slight increases of the thiobarbituric acid reactive substance levels, although no statistically significant differences from the control experiments were computable. Reoxygenation led to an enhancement of thiobarbituric acid reactive substances production. This effect was observed with and without hypoxic pretreatment (tab. 1,2).

\section{Discussion}

The aim of this study was to determine cellular metabolic conditions after different periods of hypoxia or normoxia followed by reoxygenation. Thiobarbituric acid reactive substance formation as a measure for oxygen-derived free radical activity was also investigated. This was of special interest, since in contrast to the endothelial cells of many other species, human endothelial cells exhibit no measurable activities of xanthine oxidase using radioactive substrates under normoxic, hypoxic and hyperoxic conditions (19). Xanthine oxidase is ${ }^{\circ}$ reported to be one of the main sources for the intracellu-
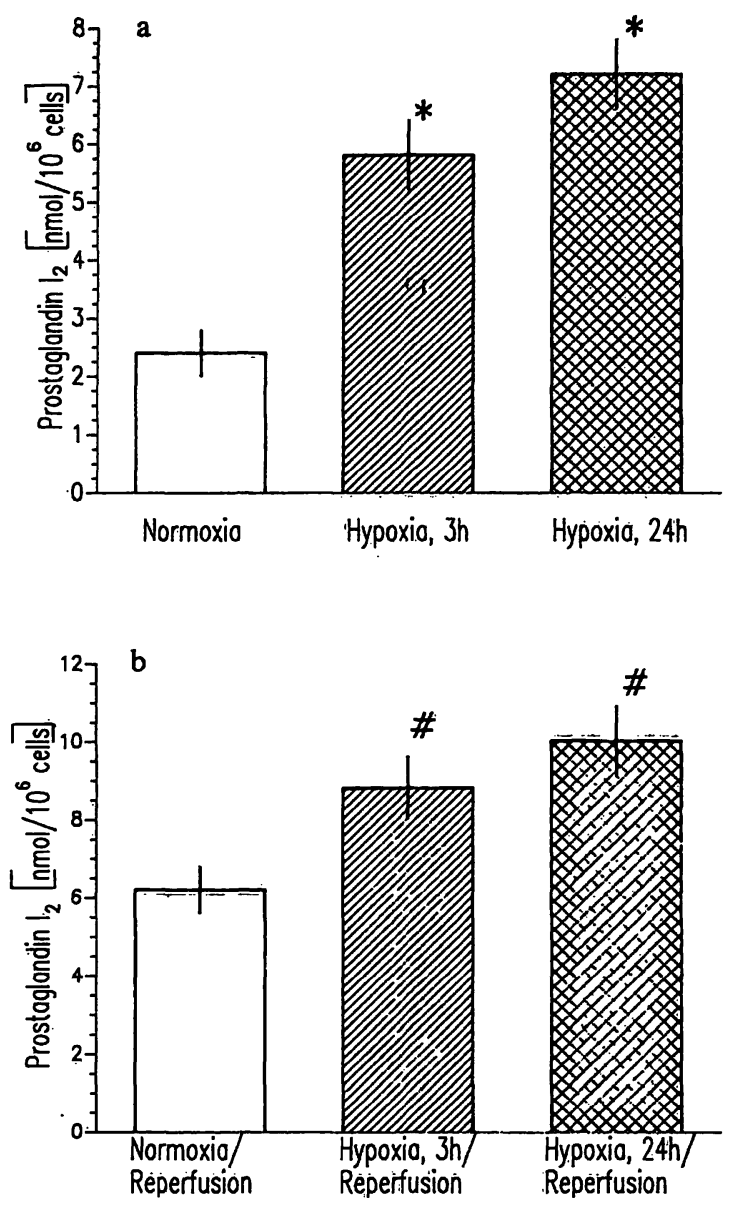

Fig. 2 Prostaglandin $I_{2}$ (measured as 6-keto-prostaglandin $F_{1 \alpha}$ ) release from human umbilical venous endothelial cells after $3 \mathrm{~h}$ and $24 \mathrm{~h}$ of hypoxia before (a) and after $60 \mathrm{~min}$ of reoxygenation (b). Significant differences compared with normoxic controls: $*=(p<0.001), \#=(p<0.05), n=10$.

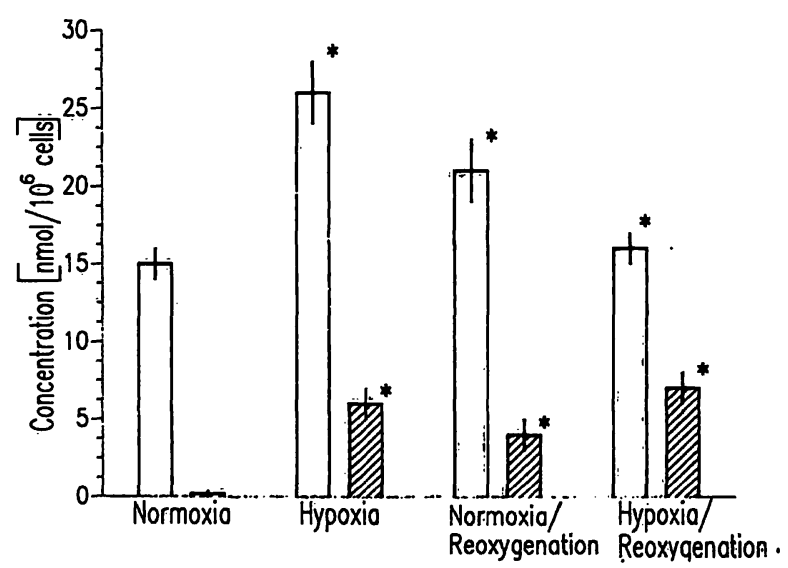

Fig. 3 Intracellular content of reduced glutathione $(\square)$ and oxidised glutathione $(\mathbb{Z})$ in humañ umbilical venous endothelial cells after $3 \mathrm{~h}$ hypoxia followed by $60 \mathrm{~min}$ of reoxygenation.

* = Significant differences compared with normoxic controls $(\mathrm{p}<0.001), \mathrm{n}=9$.

lar produced oxygen derived free radicals during tissue hypoxia (6).

Long periods of hypoxia ( $3 \mathrm{~h}, 24 \mathrm{~h}$ ) were necessary, since in contrast to physiological conditions, cultured 
endothelial cells are not exposed to shear stress, thus requiring a lower level of metabolic activity to maintain their function. The lack of oxygen leads to massive changes in the cellular steady state. This was supported by the fact that glucose consumption showed marked changes only after $24 \mathrm{~h}$ of hypoxia, indicating the change from oxidative phosphorylation to anaerobic glycolysis (20), and resulting in a reduced production of high energy phosphates. The creatine phosphate content reacted more sensitively than ATP, which decreased after longer periods of hypoxia. This is in accordance with the results of Jennings et al. from the study of myocardial ischemia (21).

Although Madden et al. (22) reported the inactivation of cyclooxygenase under hypoxic conditions, we observed an increased prostaglandin $I_{2}$ release during hypoxia. One explanation could be the activation of phospholipases by hypoxia, resulting in an increased degradation of phospholipids $(23,24)$. During the first $3 \mathrm{~h}$ of hypoxia more prostaglandin $\mathrm{I}_{2}$ was released than in the following 21 h. Similar results were obtained by Palluy et al. (25) and also by Farber et al. (26), who suggest a transient activation of cyclooxygenase by hypoxia. Although thiobarbituric acid reactive substance formation was increased, reoxygenation was rapidly answered by the release of prostaglandin $I_{2}$, which seemed contrary to the well established opinion that low levels of thiobarbituric acid reactive substances stimulate and high levels inhibit the activation of cyclooxygenase $(27,28)$. Experiments using $\mathrm{H}_{2} \mathrm{O}_{2}$ as an oxygen radical generating system showed a release of prostaglandin $\mathrm{I}_{2}$ concomitant with increasing rates of lipid peroxide formation (29). Therefore it seems obvious that the onset of reoxygenation activates cyclooxygenase and longer periods of reoxygenation depress cyclooxygenase activity.

As mentioned above, reoxygenation after $3 \mathrm{~h}$ of hypoxia induced an increased consumption of reduced glutathione, a further increase in oxidised glutathione and the restoration of total high energy phosphates. A different situation occurred when $24 \mathrm{~h}$ of hypoxia was followed by reperfusion. No reduced glutathione could be detected and the total high energy phosphate content was dramatically reduced. Schimke et al. have shown that increasing concentrations of $\mathrm{H}_{2} \mathrm{O}_{2}$ primarily lead to an increased content of high energy phosphates followed by a breakdown (30). Therefore injury during reoxygenation is probably due to enhanced radical production. If the antioxidative capacity and cellular energy pools are exhausted by longer periods of hypoxia, reoxygenation will lead to irreversible cell damage. In contrast, the hyperoxic conditions used in this study induced thiobarbituric acid reactive substance formation without prior hypoxia. This strongly suggests that the antioxidative capacity of the normoxic cells is not sufficient to prevent the general lipid peroxidation induced by exposure to high concentrations of oxygen.

\section{References}

1. Zweier, J. L., Kuppusamy, P. \& Lutty, G. A. (1988) Measurement of endothelial cell free radical generation: Evidence for a central mechanism of free radical injury in post ischemic tissues. Proc. Natl. Acad. Sci. USA 85, 4046-1050.

2. Raytch, R. E., Chuknyiska, R. S. \& Bulkley, G. B. (1987) The primary localization of free radical generation after anoxia/ reoxygenation in isolated endothelial cells. Surgery 102, $122-131$.

3. Forman, H. J. \& Boveris, A. (1982) Superoxide radical and hydrogen peroxide in mitochondria. In: Free Radicals in Biology (Pryor, W. A., ed.) Vol. 5, pp. 65-90, Academic Press, New York.

4. Gabig, T. G., Kipnes, R. S. \& Babior, B. M. (1978) Solubilization of the $\mathrm{O}_{2}$-forming activity responsible for the respiratory burst in human neutrophils. J. Biol. Chem. 253, 6663-6665.

5. Palluy, O., Morliere, L., Gris, J. Ch., Bonne, C. \& Modat, G. (1992) Hypoxia/reoxygenation stimulates endothelium to promote neutrophil adhesion. Free Rad. Biol. Med. 13, 21-30.

6. Granger, D. N., Hollwarth, M. E. \& Parks, D. A. (1986) Ischemia-reperfusion injury: Role of oxygen-derived free radicals. Acta Physiol. Scand. Supp. 548, 47-63.

7. Whorton, A. R., Montgomery, M. E. \& Kent, R. S. (1985) Effect of hydrogen peroxide on prostaglandin and cellular integrity in cultured porcine aortic endothelial cells. J. Clin. Invest. 76, 295-302.

8. Kellog, E. W. \& Fridovich, I. (1975) Superoxide, hydrogen peroxide and singlet oxygen in lipid peroxidation by a xanthine oxidase system. J. Biol. Chem. 250, 8812-8817.

9. Aalto, T. K. \& Raivio, K. O. (1990) Adenine nucleotide depletion from endothelial cells exposed to xanthine oxidase. Am. J. Physiol. 259, C883-C888.

10. Griesmacher, A., Weigel, G., Schimke, I., Windischbauer, A. \& Müller, M. M. (1993) The $\mathrm{H}_{2} \mathrm{O}_{2}$ induced effects on purine metabolism in human endothelial cells. Free Rad. Biol. Med.: In press.

11. Watson, B. D. \& Ginsberg, M. D. (1987) Mechanism of lipid peroxidation potentiated by ischemia in brain. Upjohn Symposium/Oxygen Radicals, pp. 81-91.

12. Jaffe, E. A., Nachman, R. L., Becker, C. G. \& Minck, C. R. (1972) Culture of human endothelial cells derived from umbilical veins. J. Clin. Invest. 52, 2745-2756.

13. Haudenschild, C. C., Cotran, R. S., Gimbrone, M. A. Jr. \& Folkman, J. (1975) Fine structure of vascular endothelium in culture. J. Ultrastruct. Res. 50, 22-34.

14. Jaffe, E. A., Hoyer, L. W., Nachman, R. L. (1973) Synthesis of antihaemophilic factor antigen by cultured human endothelial cells. J. Clin. Invest. 52, 2757-2763.

15. Strehler, B. L. (1974) Adenosin-5'-triphosphat- und Kreatinphosphat-Bestimmung mit Luciferase. In: Methoden der Enzymatischen Analyse (Bergmeyer, H. U., ed.) p. 2036, Academic Press, New York.

16. Griesmacher, A., Weigel, G., Schreiner, W. \& Müller, M. M. (1989) Thromboxane A2 generation by human umbilical endothelial cells. Thromb. Res. 56, 611-623.

17. Bernt, E. \& Bergmeyer, U. (1974) Glutathionc. In: Methoden der Enzymatischen Analyse (Bergmeyer, H. U., ed.) p. 1605, Academic Press, New York. 
18. Ohkawa, H., Ohishi, N. \& Yagi, K. (1979) Assay for lipidperoxides in animal tissues by thiobarbituric acid reaction. Anal. Biochem. 95, 351-355.

19. Raivio, K. O. \& Aalto, T. K. (1991) Endothelial cells and ischemia-reperfusion (I/R) injury. Intern. J. Purine Pyrimidine Res. 2, 79 .

20. Mertens, S., Noll, T., Spahr, R. \& Krützenfeld and Piper, H. M. (1990) Energetic response of coronary endothelial cells to hypoxia. Am. J. Physiol. 258, H689-H694.

21. Jennings, R. B. \& Steenbergen C. (1985) Nucleotide metabolism and cellular damage in myocardial ischemia. Ann. Rev. Physiol. 47, 727-749.

22. Madden, M: C., Vender, R. L. \& Friedman, M. (1986) Effect of hypoxia on prostacyclin production in cultured pulmonary artery endothelium. Prostaglandins 31, 1049-1062.

23. Kawaguchi, H. \& Yasuda, H. (1988) Prostacyclin biosynthesis and phospholipase activity in hypoxic rat myocardium. Circ. Res. 62, 1175-1181.

24. Busse, R., Pohl, U., Kellner, C. \& Klemm, U. (1989) Endothelial cells are involved in the vasodilatory response to hypoxia. Europ. J. Physiol. 397, 78-80.

25. Palluy, O., Bonne, C. \& Modat, G. (1991) Hypoxia/reoxygenation alters endothelial prostacyclin synthesis-protection by superoxide dismutase. Free Rad. Biol. 11, 269-275.
26. Farber, H. W. \& Barnett, H. F. (1991) Differences in prostaglandin metabolism in cultured aortic and pulmonary arterial endothelial cells exposed to acute and chronic hypoxia. Circ. Res. 68, 1446-1457.

27. Warso, M. A. \& Lands, W. E. M. (1983) Lipid peroxidation in relation to prostacyclin and thromboxane physiology and pathophysiology. Brit. Med. Bull. 39, 277-288.

28. Hemler, M. E., Lands, W. E. M. (1979) Evidence for a peroxide initiated free radical mechanism of prostaglandin biosynthesis. J. Biol. Chem. 255, 6253-6261.

29. Müller, M. M., Griesmacher, A. \& Weigel, G. (1991) Zur Pathobiochemie des Reperfusionsschadens. Berichte d. Österr. Ges. Klin. Chem. 14, 151-155.

30. Schimke, I., Griesmacher, A., Weigel, G., Holzhutter, H. G. \& Müller, M. M. (1992) Effects of reactive oxygen species on eicosanoid metabolism in human endothelial cells. Prostaglandins $43,281-292$.

Dr. Andrea Griesmacher

II. Dept. of Surgery

Clinical Biochemistry

University of Vienna

Spitalgasse 23

A-1090 Vienna

Austria 